\begin{abstract}
Iranica
Abstracta Iranica Revue bibliographique pour le domaine irano-aryen

Volume 32-33 | 2013

Comptes rendus des publications de 2009-2010
\end{abstract}

\title{
Javier Álvarez-Món. Notes on the 'Elamite’ Garment of Cyrus the Great
}

\section{Rémy Boucharlat}

\section{(2) OpenEdition}

1 Journals

\section{Édition électronique}

URL : http://journals.openedition.org/abstractairanica/40133

DOI : 10.4000/abstractairanica.40133

ISSN : 1961-960X

Éditeur :

CNRS (UMR 7528 Mondes iraniens et indiens), Éditions de l'IFRI

\section{Édition imprimée}

Date de publication : 1 décembre 2013

ISSN : 0240-8910

\section{Référence électronique}

Rémy Boucharlat, « Javier Álvarez-Món. Notes on the 'Elamite' Garment of Cyrus the Great », Abstracta Iranica [En ligne], Volume 32-33 | 2013, document 22, mis en ligne le 01 juillet 2016, consulté le 26 septembre 2020. URL : http://journals.openedition.org/abstractairanica/40133 ; DOI : https://doi.org/ 10.4000 /abstractairanica.40133

Ce document a été généré automatiquement le 26 septembre 2020.

Tous droits réservés 


\title{
Javier Álvarez-Món. Notes on the 'Elamite' Garment of Cyrus the Great
}

\author{
Rémy Boucharlat
}

\section{RÉFÉRENCE}

« Notes on the 'Elamite' Garment of Cyrus the Great ». The Antiquaries Journal, 89, 2009, p. 21-33.

1 La Chronique de Nabonide relate des évènements entre 556 et peu après 539, date de l'entrée de Cyrus à Babylone. Dans ce texte, il est spécifié que pour son investiture Cyrus portait une robe élamite - non pas perse ou élamo-perse (voir la robe du « génie ailé » ou Cyrus sur la Porte $\mathrm{R}$ de Pasargades). Il apparaît que non seulement le conquérant n'a pas cherché à revêtir la robe babylonienne, mais, selon J.A.-M., la Chronique fait explicitement référence aux Elamites, voisins de l'est, puissants ou dangereux dans le passé pour Babylone. Parce que Cyrus est appelé ailleurs roi d'Anshan ou de Parsu, le pays d'origine serait bien la région d'Anshan/Malyan au nordouest de Persépolis. Le problème est que, selon l'archéologie et l'épigraphie, Anshan n'est presque plus rien depuis des siècles à l'époque de Cyrus.

\section{AUTEURS}

RÉMY BOUCHARLAT

CNRS, Lyon 